\title{
Human Immunodeficiency Virus Infection Induces Both Polyclonal and Virus-specific B Cell Activation
}

\author{
Akira Shirai, ${ }^{\star}$ Mark Cosentino, ${ }^{\star}$ Susan F. Leitman-Klinman, ${ }^{\ddagger}$ and Dennis M. Klinman* \\ *Laboratory of Retrovirus Research, Division of Virology, Center for Biologics, Food and Drug Administration, Bethesda, Maryland \\ 20892; and ${ }^{\ddagger}$ Aphoresis Section, Department of Transfusion Medicine, National Institutes of Health, Bethesda, Maryland 20892
}

\begin{abstract}
Peripheral blood lymphocytes (PBL) were obtained from HIV1-infected patients at different stages of disease. The absolute number of IgM-, IgG-, and IgA-producing lymphocytes per $10^{6}$ PBL was increased 2.8-, 3.4-, and 1.9-fold, respectively, compared with normal controls. 2-17\% of IgG-secreting patient cells reacted with the gp160 envelope glycoprotein of HIV-1 (a 737-fold increase over background), while 1-9\% reacted with p24 (140-fold over background). In addition to this HIV-specific $B$ cell activation, the number of lymphocytes reactive with nonviral antigens such as DNA, myosin, actin, trinitrophenylated keyhole limpet hemocyanin, and ovalbumin was increased by a mean of 17.9-fold. Evidence suggests that the latter changes reflect an HIV-induced polyclonal B cell activation unrelated to the production of anti-HIV antibodies. For example, the proportion of IgG anti-gp160- and anti-p24-secreting lymphocytes declined in patients with advanced disease, whereas the number of $B$ cells producing antibodies to nonHIV antigens rose. Moreover, CD4 cell count and T4/T8 ratio showed a significant inverse correlation with the degree of polyclonal activation but not with anti-HIV responsiveness. These observations demonstrate that both quantitative and qualitative changes in B cell activation accompany (and may be predictive of) disease progression in HIV-infected individuals. (J. Clin. Invest. 1992. 89:561-566.) Key words: HIV • AIDS • B cells • polyclonal activation • gp 160
\end{abstract}

\section{Introduction}

Infection with HIV-1 induces profound abnormalities in the host's immune system, including a loss of $\mathrm{CD}_{4}^{+} \mathrm{T}$ cells (1-5), suppression of responses to T-dependent antigens (6-9), and abnormal activation of B lymphocytes $(9,10)$. In the first year after infection, many patients develop hypergammaglobulinemia (11-13), characterized by increased levels of serum antibodies reactive with self antigens (such as $\mathrm{T}$ cells and nuclear determinants; foreign antigens such as trinitrophenyl (TNP) ${ }^{1}$ and sheep red blood cells; and HIV viral proteins, including gp160 and p24 [14-22]).

This B cell activation was initially believed to be "polyclonal" in nature since: $(a)$ it included antibodies reactive with a

Address correspondence to Dennis M. Klinman, Bldg. 29A, Rm. 3 D 02, CBER/FDA, Bethesda, MD 20892.

Received for publication 28 February 1991 and in revised form 12 September 1991

1. Abbreviations used in this paper: ASC, antibody-secreting cell; $\mathrm{PBL}$ peripheral blood leukocytes; TNP, trinitrophenyl; TNP-KLH, trinitrophenylated keyhole limpet hemocyanin.

The Journal of Clinical Investigation, Inc.

Volume 89, February 1992, 561-566 large number of different antigens (9); $(b)$ components of the HIV virus (especially gp41) were reported to induce normal B cells to polyclonally proliferate and secrete Ig in vitro (23-26); and $(c)$ the number of Ig-secreting lymphocytes increased in HIV-infected patients, whereas the total number and proportion of peripheral blood B cells did not $(3,9,27,28)$. Yet more recent studies find little evidence of polyclonal memory B cell activation in $\mathrm{HIV}^{+}$patients $(29,30)$ and the stimulatory effects of gp41 are now regarded primarily as a reflection of in vitro culture conditions $(31,32)$. It has recently been proposed that the B cell activation induced by HIV-1 infection is primarily directed against the virus itself $(30,32)$. For example, limiting dilution analysis of $\mathrm{PBL}$ from AIDS patients cultured in vitro showed that $20-100 \%$ of these B cells produced anti-HIV antibodies $(30,33)$.

The humoral immune response mounted by retrovirus-infected individuals may be important in regulating HIV replication/spread in vivo (34-36), preventing superinfection by other pathogens, and/or mediating autoimmune damage to host tissues (37-41). It is therefore important to determine: $(a)$ the processes involved in regulating B cell activation in HIV-1-infected patients, and $(b)$ whether changes in these processes are associated with disease progression. In addition, abnormal B cell activation is a feature of other infectious diseases (e.g., EBV, cytomegalovirus, and parasitic infections [42-45]) such that studies of HIV-1 might yield insights relevant to other diseases as well.

To examine the nature of the B cell activation present in $\mathrm{HIV}^{+}$individuals, investigators have monitored changes in the concentration of serum antibodies and the activation state of lymphocytes cultured in vitro $(6,29,30,33,46,47)$. While both of these approaches have value, it is now possible to directly monitor the number and antigenic specificity of B cells activated as a consequence of HIV infection. This can be accomplished by using an ELISA spot assay which is sensitive enough to detect the Ig produced by single freshly isolated in vivo activated peripheral blood lymphocytes (PBL; 48-51).

We used the ELISA spot technique to study large numbers of HIV-infected patients with Center for Disease Control (CDC) class II, III, and IV disease. Results indicate that HIV infection induced both virus-specific and polyclonal B cell activation. These two types of $B$ cell activation appeared to be regulated independently, in that $(a) \mathrm{HIV}$-specific responses declined as a function of disease severity while polyclonal responses increased, and $(b)$ only polyclonal responses correlated significantly with $\mathrm{CD}_{4}$ cell number and $\mathrm{CD}_{4} / \mathrm{CD}_{8}$ ratio.

\section{Methods}

Subjects. A total of 86 HIV-positive patients (23 with CDC class II disease, 55 with class III, and 8 with class IV disease) were studied. All were followed as outpatients in the Department of Transfusion Medicine of the National Institutes of Health (NIH) Clinical Center. 20 of 
these patients were being treated with zidovudine. 51 seronegative donors were used as controls.

ELISA spot assay of human cells. Flat-bottomed Immulon I microtiter plates (Dynatech Labs, Inc., Chantilly, VA) were coated with goat anti-human Ig (Boerhinger Mannheim Corp., Indianapolis, IN), or soluble $\mathrm{Ag}$ (including ssDNA, myosin, actin, ovalbumin, trinitrophenylated keyhole limpet hemocyanin (TNP-KLH), the p24 Gag of HIV-1 [hereafter p24, kind gift of Keith Higgings, Chiron Corporation, Emeryville, CA], or glycosylated recombinant GP160 [MicroGeneSys, Inc., Meriden, CT]) and then blocked with $1 \% \mathrm{PBS}$ as previously described $(50,52)$.

Peripheral blood mononuclear cells were separated by density gradient centrifugation over Ficoll-Hypaque (Pharmacia Fine Chemicals, Piscataway, NJ). White blood cells recovered from the interface were washed six times in medium consisting of RPMI 1640 supplemented with $2.5 \%$ FCS. These cells were resuspended at a concentration of 10 $\times 10^{6} / \mathrm{ml}$. Serial dilutions of freshly isolated PBL, starting with $10^{6}$ cells/well, were incubated on Ag-coated plates for $9-10 \mathrm{~h}$ at $37^{\circ} \mathrm{C}$ in a $5 \% \mathrm{CO}^{2}$ in air incubator. The cells were then washed away with PBS/ $0.05 \%$ Tween 20 and the plates overlaid with phosphatase-conjugated antibodies to human IgG, IgM, and IgA (Boerhinger Mannheim Corp.). The antibodies produced by individual B cells that bound to antigen on the plate were visualized by addition of a 5-bromo-3-chloro4-indolyl phosphatase solution (Sigma Chemical Co., St. Louis, MO) in a low melt agarose kept at $56^{\circ} \mathrm{C}$. Phosphatase acts on this substrate to produce a blue spot that cannot diffuse through the agarose once it solidifies at room temperature (48). That dilution of cells producing $\sim 20-30$ spots/well was used to calculate the total number of antibodysecreting cells (ASC) for each antigen per $10^{6} \mathrm{PBL}$.

The presence of BSA in the FCS used to conduct these assays completely inhibited the binding of BSA-specific antibodies to BSAblocked plates, giving the assays zero background. The sensitivity and specificity of this assay has been documented in antigen inhibition tests and in studies involving antigen-specific hybridoma cell lines (48-50).

Statistical analysis. Correlation coefficients were determined using Pearson's procedure based on linear regression analysis. Statistical significance was determined used a two-tailed $t$ test unless otherwise described.

\section{Results}

Number and specificity of Ig-secreting cells in HIV-1-infected patients. The frequency of PBL secreting IgG, IgM, or IgA antibodies in $86 \mathrm{HIV}^{+}$individuals was compared with that of 51 normal donors. As seen in Table I, the number of cells secreting Ig of each isotype was increased 1.9-3.4-fold in the patient group. An antigen-specific ELISA spot assay sensitive enough to detect one Ab-secreting cell among $10^{6} \mathrm{PBL}$ was used to determine the specificity of the antibodies produced by these cells. This assay was selected on the basis of its $(a)>20$-fold higher sensitivity for spontaneously secreted Ig compared with conventional ELISAs (48-50, 53, and data not shown), (b) freedom from artifacts induced by prolonged in vitro culture and/ or mitogenic stimulation (54), and (c) ability to provide an accurate measure of $B$ cell activation in vivo $(48,50,53,55)$.

Among HIV-infected individuals, the repertoire of IgG-secreting cells was significantly skewed toward reactivity against HIV-associated antigens. Antibody from $7.1 \%$ of all IgG-producing cells specifically bound to recombinant purified $\mathrm{HIV}_{\text {IIIB }}$ gp160, a 737-fold increase over control background $(P$ $<0.0001$, Table I). Antibody from an additional 3\% of IgG-secreting cells bound to the p24 antigen of HIV (140-fold over background, $P<0.001$ ).

By comparison, the repertoire of IgM- and IgA-secreting cells was not skewed toward the production of gp160 or p24 reactive antibodies. These PBL exhibited a general and proportional increase in reactivity against a diverse panel of autoantigens (DNA, myosin, actin) and conventional antigens (TNP$\mathrm{KLH}$, ovalbumin), consistent with a process of polyclonal B cell activation (Table I). The number of cells secreting IgG antibodies against members of this antigen panel was increased 9-25-fold compared with controls (mean increase, 17.9-fold). This indicated either that cross-reactive $B$ cells were being poly-

Table I. Number of B Cells Secreting Ab Reactive with Each Antigen

\begin{tabular}{|c|c|c|c|c|c|c|c|c|c|}
\hline & & Total & gp160 & p24 & DNA & TNP & MYO & ACT & OVA \\
\hline \multicolumn{10}{|l|}{ IgG } \\
\hline \multirow[t]{2}{*}{$\mathrm{HIV}^{+}$} & Mean & 10,722 & 737 & 329 & 82.8 & 70.4 & 15.2 & 31.8 & 43.7 \\
\hline & SE & 491 & 93 & 94 & 7.9 & 9.4 & 2.2 & 4.6 & 5.2 \\
\hline \multirow[t]{2}{*}{ Normal } & Mean & 3,118 & 1.0 & 2.3 & 3.3 & 2.8 & 1.7 & 1.6 & 4.0 \\
\hline & $\mathrm{SE}$ & 179 & 0.2 & 0.7 & 0.4 & 0.5 & 0.5 & 0.3 & 0.4 \\
\hline Ratio $\mathrm{HIV}^{+} /$normal & & 3.4 & $737^{*}$ & $140^{*}$ & $25.1^{\ddagger}$ & $24.8^{\ddagger}$ & $9.1^{8}$ & $19.4^{\ddagger}$ & $10.9^{\ddagger}$ \\
\hline \multicolumn{10}{|l|}{ IgM } \\
\hline \multirow[t]{2}{*}{$\mathrm{HIV}^{+}$} & Mean & 327 & 11.4 & 29.8 & 15.8 & 13.6 & 14.9 & 16.1 & 8.1 \\
\hline & SE & 47 & 3.7 & 7.4 & 3.3 & 3.6 & 6.3 & 6.0 & 2.6 \\
\hline \multirow[t]{2}{*}{ Normal } & Mean & 116 & 3.3 & 14.5 & 3.9 & 2.6 & 2.7 & 2.3 & 2.1 \\
\hline & SE & 13 & 0.5 & 4.5 & 1.0 & 0.9 & 0.8 & 1.6 & 0.5 \\
\hline Ratio $\mathrm{HIV}^{+} /$normal & & 2.8 & 3.5 & 2.1 & 4.0 & 5.3 & 5.5 & 6.9 & 3.8 \\
\hline \multicolumn{10}{|l|}{$\operatorname{Ig} \mathrm{A}$} \\
\hline \multirow[t]{2}{*}{$\mathrm{HIV}^{+}$} & Mean & 718 & 1.6 & & 1.2 & 1.7 & & & 1.2 \\
\hline & $\mathrm{SE}$ & 161 & 0.4 & & 0.6 & 0.9 & & & 0.6 \\
\hline \multirow[t]{2}{*}{ Normal } & Mean & 374 & 0.8 & & 0.3 & 0.6 & & & 0.3 \\
\hline & SE & 70 & 0.3 & & 0.2 & 0.3 & & & 0.2 \\
\hline Ratio $\mathrm{HIV}^{+} /$normal & & 1.9 & 2.0 & & 3.5 & 3.0 & & & 3.5 \\
\hline
\end{tabular}

The number of cells secreting antibody reactive with the HIV $\mathrm{IUB}_{\mathrm{B}} \mathrm{gp} 160$ and p24, the autoantigens DNA, actin (ACT), and myosin (MYO), and the conventional antigens ovalbumin (OVA) and TNP-KLH were measured using the ELISA spot assay. Results represent the mean (and SE) of Ig-secreting cells $/ 10^{6} \mathrm{PBL}$ from up to $86 \mathrm{HIV}$-infected donors and 51 normal controls. ${ }^{*} P<0.005 ;{ }^{\ddagger} P<0.01 ;{ }^{8} P<0.05$. 
clonally activated or that HIV-reactive lymphocytes were producing cross-reactive antibodies.

Relationship between HIV-specific and polyclonally activated $B$ cells. We investigated the possibility that the IgG antibodies reactive with members of the antigen panel were induced by stimulation of, or reflected cross-reactive binding by, HIV-specific B cells. As seen in Fig. 1 and Table II, the number of B cells reactive with DNA, TNP, actin, ovalbumin, and myosin showed strong positive correlations with one another and with the total number of IgG-secreting cells present in HIV-infected patients. In contrast, the number of anti-gp160and anti-p24-secreting cells were positively correlated with one another but not with cells producing non-HIV binding antibodies. These findings suggest that polyclonal IgG production in $\mathrm{HIV}^{+}$individuals was independent of HIV-specific B cell activation.

Relationship between disease progression, $T$ cell abnormalities, and $\mathrm{B}$ cell activation in $\mathrm{HIV}^{+}$individuals. We investigated whether the number of antigen-specific IgG-secreting cells in the peripheral blood correlated with disease progression. Results indicate that the proportion of IgG anti-HIV-secreting cells was significantly lower among patients with CDC class IV than class II or III disease ( $P<0.01$, two-sample $t$ test; Fig. 2$)$. Conversely, the degree of polyclonal $B$ cell activation was significantly increased among patients with CDC class IV disease ( $P$ $<0.005$ ).

Another interesting correlation was noted between $\mathrm{CD}_{4}^{+}$ count, $\mathrm{CD}_{4} / \mathrm{CD}_{8}$ ratio, and the degree of polyclonal activation. As seen in Table III, the proportion of cells secreting IgG antibodies against non-HIV antigens showed a significant inverse correlation with these parameters, unlike those reactive with HIV. In addition, the total number of IgG- and IgA-producing cells, and serum IgM and IgA concentration, showed significant inverse correlations with CD4 count and/or CD4/CD8 ratio (Table IV).

\section{Discussion}

Hypergammaglobulinemia and increased B cell activation are common early features of HIV infection (9-13). This work

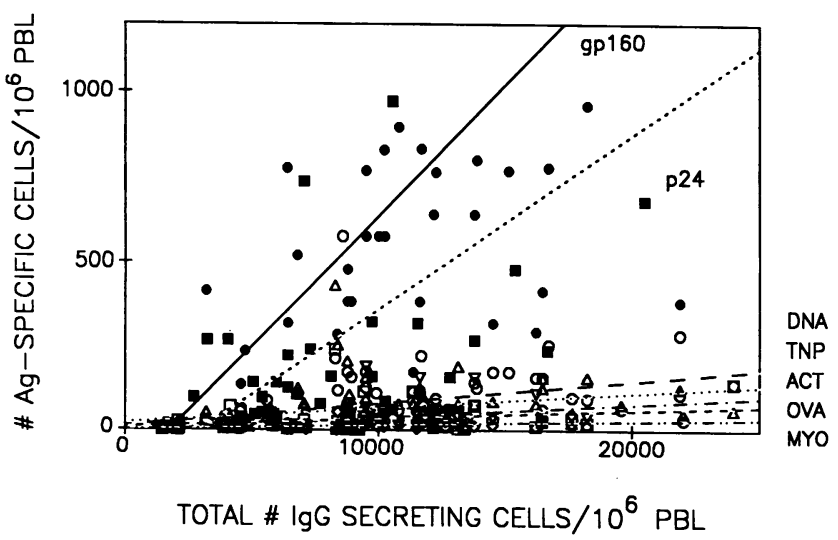

Figure 1. The number of cells secreting IgG antibodies reactive with each antigen gp160 (•), p24 (๑), DNA (०), TNP-KLH ( $\triangle$ ), actin ( $\square$ ), ovalbumin $(\nabla)$, and myosin $(\diamond)$ was plotted as a function of the total number of IgG-secreting cells $/ 10^{6} \mathrm{PBL}$ from each patient. For all plots, the correlation coefficient of Ig-secreting versus Ag-specific cells had an $r \geq 0.28$ and a $P<0.05$.
Table II. Correlation Matrix among B Cells Secreting IgG Antibodies Reactive with Different Antigens

\begin{tabular}{lcccccc}
\hline & p24 & DNA & TNP & MYO & ACT & OVA \\
\hline gp160 & $0.51^{*}$ & -0.06 & 0.10 & -0.06 & -0.10 & -0.04 \\
DNA & & & $0.81^{*}$ & $0.68^{*}$ & $0.72^{*}$ & $0.65^{*}$ \\
TNP & & & & $0.77^{*}$ & $0.77^{*}$ & $0.65^{*}$ \\
MYO & & & & & $0.61^{*}$ & $0.68^{*}$ \\
ACT & & & & & & $0.66^{*}$
\end{tabular}

Data represent Sperman's rank correlation coefficients based on 20 59 determinants for each pair of variables. Statistical significance was determined using a nonparametric procedure. MYO, myosin; ACT, actin; OVA, ovalbumin.

$* P<0.005$.

documents that both virus-specific IgG and polyclonal IgM and IgA responses are present in HIV-infected individuals. These two forms of B cell activation appear to be independently regulated, since $(a)$ the extent of gp 160-and p24-specific $B$ cell activation did not correlate with that of polyclonal B cell stimulation, $(b)$ polyclonal but not HIV-specific B cell activation varied as a function of $\mathrm{CD}_{4}$ count and $\mathrm{CD}_{4} / \mathrm{CD}_{8}$ ratio, and (c) HIV-specific B cell activation decreased while polyclonal B cell activation increased among patients with advanced disease.

This work established the number of lymphocytes secreting anti-gp160 antibodies in different patient populations. We found that $2-17 \%$ (mean $7.1 \%$ ) of IgG-producing cells in HIVinfected individuals reacted with recombinant purified gp 160 , while $1-9 \%$ reacted with p24 (Table I). These frequencies are consistent both with the number of anti-HIV-secreting cells induced in mice immunized and boosted with these antigens (56) and with the frequency of antigen-specific $B$ cells found in other diseases involving chronic immunostimulation (51).

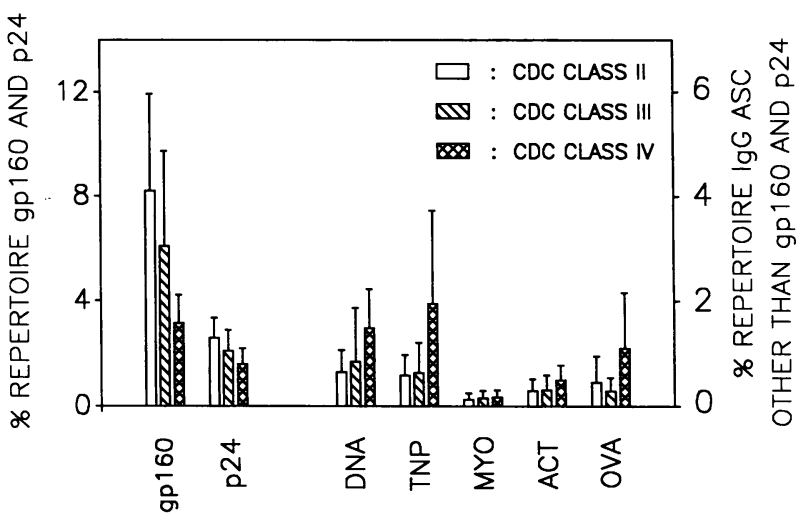

Figure 2. Percent of Ig-secreting cells vs stage of disease. The percent of cells secreting $\operatorname{IgG}$ antibodies against each antigen was plotted as a function of CDC disease stage. There was a significant decline ( $P$ $<0.01)$ in the number of B cells secreting anti-gpl60 antibodies among patients with CDC stage IV disease, as opposed to a significant increase $(P<.005)$ in the frequency of cells polyclonally activated against other antigens. This trend was maintained when only patients being treated with zidovudine were analyzed $(n=4, \mathrm{CDC}$ stage II; $n=5$, CDC stage III; $n=4$, CDC stage IV). The total number of IgG-secreting cells $/ 10^{6} \mathrm{PBL}$ expressed by patients was $9,100 \pm 4,500$

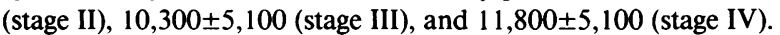


Table III. Correlation between the Frequency of Cells Secreting Antigen-specific IgG Antibodies and T Cell Parameters

\begin{tabular}{lcc}
\hline Antigen & T4 & T4/T8 \\
\hline gp160 & -0.06 & 0.10 \\
p24 & 0.07 & 0.05 \\
DNA & $0.28^{*}$ & $-0.34^{\ddagger}$ \\
TNP & $-0.29^{*}$ & -0.21 \\
MYO & $-0.41^{*}$ & $-0.45^{\ddagger}$ \\
ACT & $-0.38^{*}$ & $-0.47^{\ddagger}$ \\
OVA & $-0.28^{*}$ & $-0.34^{*}$
\end{tabular}

Data represent Pearson's coefficient of correlation based on 35-68 determinants for each pair of variables. MYO, myosin; ACT, actin; OVA, ovalbumin.

${ }^{*} P<0.05,{ }^{\ddagger} P<0.01$.

They also support the observation that gp160 represents the immunodominant antigen expressed by HIV.

Of interest, the frequency of B cells producing antibodies against viral antigens was significantly lower in patients with CDC stage IV than stage II or III disease (Fig. 2). This finding is consistent with evidence from other investigators showing that disease progression is associated with a decrease in $\mathrm{Ab}$ titer against HIV proteins (57-60) and suggests that an active humoral response against HIV may delay disease progression (or alternatively, that the ability to maintain such a response degrades as immune status declines). A possible confounding influence on these studies was the more frequent use of zidovudine by patients with advanced disease. To control for this variable, all patients receiving zidovudine therapy were analyzed independently. Again, those with the most advanced disease expressed the lowest numbers of anti-gp 160- and anti-p24secreting B cells (Fig. 2, legend).

Amadori et al. have reported that $20-100 \%$ of B cells from the peripheral blood of AIDS and AIDS-related complex patients produce anti-HIV antibodies (30). Our estimate of p24and gp160-specific B cells is somewhat lower, a difference we attribute to our use of the ELISA spot assay to study in vivo activated lymphocytes versus Amadori's analysis of in vitro cultured cells. As we and others have shown, in vitro culture and mitogen stimulation can alter the repertoire of B cells induced to secrete $\mathrm{Ig}$ (54). Moreover, it seems unlikely that a

Table IV. Correlation between the Number of Ig-secreting Cells and T Cell Parameters

\begin{tabular}{lll}
\hline & T4 & T4/T8 \\
\hline IgG-ASC & $-0.26^{*}$ & $-0.33^{\ddagger}$ \\
Serum IgG & -0.10 & -0.20 \\
IgM-ASC & -0.13 & -0.11 \\
Serum IgM & -0.15 & $-0.33^{\ddagger}$ \\
IgA-ASC & $-0.32^{*}$ & -0.20 \\
Serum IgA & $-0.52^{\S}$ & $-0.40^{\S}$
\end{tabular}

Correlation coefficients determined as described in Table III. The correlation between serum Ig level and number of Ig-secreting cells was $\mathbf{0 . 4 6}$ for IgG, $\mathbf{0 . 1 3}$ for IgM, and $\mathbf{0 . 3 4}$ for IgA.

${ }^{*} P<0.05 ;{ }^{\ddagger} P<0.01 ;{ }^{8} P<0.005$. majority of an individual's expressed repertoire would be directed against a single pathogen, since the humoral immune system is constantly being stimulated by numerous exogenous antigens. Ongoing studies of sera and mitogen-stimulated PBL from patients conducted in our lab also find that HIV-specific antibodies constitute $<30 \%$ of the total immune response (data not shown).

While technically more difficult than conventional studies of serum Ig, the ELISA spot assay provided data on the state of $B$ cell activation in vivo unobtainable by other methods. In addition, the ELISA spot assay is unaffected by factors such as the rate of $\mathrm{Ig}$ catabolism or the presence of $\mathrm{Ag}$, variables that influence serum $\mathrm{Ab}$ levels. The ELISA spot assay has been compared to conventional ELISAs designed to detect Ig spontaneously secreted by $B$ cells cultured in vitro. While these two techniques yield concordant results $\left(r^{2}=0.63-0.87\right.$; reference 61 and data not shown), the ELIspot assay has repeatedly been found to be considerably more sensitive (48-50). A limitation inherent to our study was that only B cells from the peripheral circulation could be analyzed. Since large numbers of activated $B$ cells may be present in the spleen and lymph nodes, our results might not reflect the state of $B$ cell activation in the patient as a whole. Indeed, this limitation may account for the differences noted between the level of certain serum Ig isotypes and numbers of Ig-secreting cells detected in this work (Table IV).

Polyclonal activation appeared to be the primary process responsible for the stimulation of IgM- and IgA-secreting lymphocytes in HIV-infected individuals (Table I). Leitman et al. have shown that increased serum IgA levels are strongly predictive of disease progression (62). While the cause of this polyclonal activation is unclear, it may reflect direct immunostimulation by one or more components of the virus (such as gp41 [23-26]), bystander stimulation due to lymphokines released by HIV-specific T cells (63), and/or abnormalities in immune regulation resulting from a loss of $T$ cell function. In the case of IgG-secreting cells, there was an unexpected 9-25-fold increase in the number of non-HIV reactive lymphocytes despite an increase of only 3.4-fold in the total number of IgG-producing cells (Table I). While indicative of polyclonal activation, this result further suggests that a subpopulation of highly crossreactive $\mathrm{B}$ cells might be specifically stimulated in $\mathrm{HIV}^{+}$individuals. This possibility is currently under investigation.

There was a significant inverse correlation between the number of IgG-secreting B cells among patients and their CD4 cell count, suggesting that these two processes may be causally linked (Table IV). Indeed, an association between polyclonal B cell activation and defective $T_{4}$ function has been reported in other disease states, such as experimentally induced graft-versus-host disease, murine lupus, and murine AIDS (41, 64-68).

The level of B cell activation found in HIV-infected individuals is comparable to that detected in patients with autoimmune diseases such as systemic lupus erythematosus (69). This polyclonal activation is associated both with the production of pathogenic autoantibodies (such as IgG anti-DNA) and the suppression of immune responses to foreign antigens. It is possible that pathogenic organisms (e.g., HIV, EBV, cytomegalovirus) "intentionally" induce polyclonal responses in an effort to suppress the host's capacity to mount a specific response against the pathogen. In this context, it is interesting to note the inverse correlation between polyclonal activation and HIVspecific responses manifest by patients with CDC class II and 
III versus IV disease (Fig. 2). Ongoing research may elucidate the mechanism(s) by which HIV and other pathogens abnormally activate host $B$ cells and determine the effect of this process on disease progression.

\section{References}

1. Gottlieb, M. D., R. Schroff, H. M., Schanker, J. D. Weisman, P. T. Fan, R. A. Wolf, and A. Saxon. 1981. Pneumocystis carinii pneumonia and mucosal candidiasis in previously healthy homosexual men. $N$. Engl. J. Med. 305:14251431 .

2. Mildvan, D., U. Mathur, R. W. Enlow, P. L. Romain, R. J. Winchester, C. Colp, H. Singman, B. R. Adelsberg, and I. Spigland. 1982. Opportunistic infections and immune deficiency in homosexual men. Ann. Intern. Med. 96:700704.

3. Stahl, R. E., A. Friedman-Kien, R. Dubin, M. Marmor, and S. ZollaPazner. 1982. Immunologic abnormalities in homosexual men. Am. J. Med. 73:171-178.

4. Fahey, J. L., H. Prince, M. Weaver, J. E. Groopman, B. Visscher, K. Schwartz, and R. Detels. 1984. Quantative changes in T helper or T suppressor/ cytotoxic subsets that distinguish acquired immune deficiency syndrome. Am. J. Med. 76:95-100.

5. Klatzmann, D., F. Barre-Sinoussi, M. T. Nugeyre, C. Dauguet, E. Vilmer, C. Griscelli, F. Brun-Vezinet, C. Rouzioux, J. C. Gluckman, J. C. Chermann, and L. Montagnier. 1984. Selective tropism of lymphadenopathy associated virus (LAV) for helper-inducer T lymphocytes. Science (Wash. DC). 225:59-63.

6. Mizuma, H., S. Litwin, and S. Zolla-Pazner. 1988. B-cell activation in HIV infection: relationship of spontaneous immunoglobulin secretion to various immunological parameters. Clin. Exp. Immunol. 71:410-416.

7. Prince, H. E., V. Kermain-Arab, and J. L. Fahey. 1984. Depressed IL-2 receptor expression in acquired immune deficiency and lymphoadenapathy syndromes. J. Immunol. 133:1313-1317.

8. Amman, A. J., G. Schiffman, D. Abrams, P. Volberding, J. Ziegler, and M. Conant. 1984. B cell immunodeficiency in acquired immunodeficiency syndrome. J. Am. Med. Assoc. 251:1447-1449.

9. Lane, H. C., H. Masur, L. C. Edgar, G. Whalen, A. H. Rook, and A. S Fauci. 1983. Abnormalities of B-Cell activation and immunoregulation in patients with the acquired immunodeficiency syndrome. N. Engl. J. Med. 309:453458.

10. Crawford, D. H., I. Weller, and V. Iliescu. 1984. Polyclonal activation of B cells in homosexual men. $N$. Engl. J. Med. 311:536-537.

11. Zolla-Pazner, S. 1984. B cells in the pathogenesis of AIDS. Immunol. Today. 5:289-291.

12. Fauci, A. S., A. B. Macher, D. L. Longo, H. C. Lane, A. H. Rook, H. Masur, and E. P. Gelmann. 1984. Acquired immunodeficiency syndrome: epidemiologic, clinical, immunologic and therapeutic considerations. Ann. Intern. Med. 100:92-106.

13. Nicholson, J. K. A., J. S. McDougal, T. J. Spira, G. D. Cross, B. M. Jones and E. L. Reinherz. 1984. Immunoregulatory subsets of the T helper and T suppressor cell populations in homosexual men with chronic unexplained lymphadenopathy. J. Clin. Invest. 73:191-201.

14. Warren, R. Q., E. A. Johnson, R. P. Donnelly, M. F. Lavia, and K. Y. Tsang. 1988. Specificity of anti-lymphocyte antibodies in sera from patients with AIDS-related complex (ARC) and healthy homosexuals. Clin. Exp. Immunol. 73:168-173.

15. Sonnabend, J., S. S. Witkin, and D. T. Purtilo. 1983. Acquired immunodeficiency syndrome, opportunistic infection, and malignancies in male homosexuals. J. Am. Med. Assoc. 249:2370-2374.

16. Puyanski, W., H. Jacobs, and L. P. Laing. 1984. Lymphocytotoxic antibodies against peripheral blood $\mathrm{B}$ and $\mathrm{T}$ lymphocytes in homosexuals with AIDS and ARC. AIDS Res. 1:211-220.

17. Dorsett, B., W. Cronin, V. Churna, and H. L. Iochim. 1985. Anti-lymphocyte antibodies in patients with the acquired immune deficiency syndrome. $\mathrm{Am}$ J. Med. 78:621-626.

18. Grant, M. D., M. S. Weaver, C. Tsoukas, and G. W. Hoffmann. 1990. Distribution of antibodies against denatured collagen in AIDS risk groups and homosexual AIDS patients suggests a link between autoimmunity and the immunopathogenesis of AIDS. J. Immunol. 144:1241-1250.

19. Zolla-Pazner, S. 1984. Selology. In AIDS: A Basic Guide for Clinicians. P Ebbesen, R. J. Biggar, and M. Melbye, editors. W. B. Saunders Company, Philadelphia. 151-172.

20. Allan, J. S., J. E. Coligan, F. Barin, M. F. McLane, J. G. Sodroski, C. A Rosen, W. A. Haseltine, T. H. Lee, and M. Essex. 1985. Major glycoprotein antigens that induce antibodies in AIDS patients are encoded by HTLV-III Science (Wash. DC). 228:1091-1094.

21. Brun-Vezinet, F., C. Rouzioux, F. Barre-Sinoussi, D. Klatzmann, A. G. Saimot, W. Rozenbaum, D. Christol, J. C. Gluckmann, L. Montagnier, and J. C. Chermann. 1984. Detection of IgG antibodies of lymphadenopathy-associated virus in patients with AIDS or lymphadenopathy syndrome. Lancet. 10:12531256.

22. Barin, F., M. F. McLane, J. S. Allan, T. H. Lee, J. E. Groopman, and M. Essex. 1985. Virus envelope protein of HTLV-III represents major target antigen for antibodies in AIDS patients. Science (Wash. DC). 228:1094-1096.

23. Pahwa, S., R. Pahwa, C. Saxinger, R. C. Gallo, and R. A. Good. 1985 Influences of human $\mathrm{T}$ lymphotropic virus/lymphoadenopathy associated virus on human lymphocytes: evidence of polyclonal B cell activation by banded viral preparations. Proc. Natl. Acad. Sci. USA. 82:8198-8202.

24. Schnittman, S. M., H. C. Lane, S. E. Higgins, T. Folks, and A. S. Fauci. 1986. Direct polyclonal activation of human B lymphocytes by the acquired immune deficiency syndrome virus. Science (Wash. DC). 233:1084-1086.

25. Pahwa, S., R. Pahwa, R. A. Good, R. C. Gallo, and C. Saxinger. 1986. Stimulatory and inhibitory influences of human immunodeficiency virus on normal B lymphocytes. Proc. Natl. Acad. Sci. USA. 83:9124-9128.

26. Chirmule, N., V. S. Kalyanaraman, C. Saxinger, F. Wong-Staal, J. Ghrayeb, and S. Pahwa. 1990. Localization of B-cell stimulatory activity of HIV1 to the carboxyl terminus of gp41. AIDS Res. Hum. Retroviruses. 6:299-305.

27. Rieckmann, P., G. Poli, J. H. Kehrl, and A. S. Fauci. 1991. Activated B lymphocytes from HIV-infected individuals induce virus expression in infected $\mathrm{T}$ cells. J. Exp. Med. 173:1-5.

28. Sei, Y., P. H. Tsang, R. J. Patrello, and J. G. Bikesi. 1987. Multiple dysfunction in developmental and activation stages of $\mathrm{T}$ lymphocytes, B lymphocytes and monocytes in ARC and AIDS patients. Immunol. Lett. 16:157-162.

29. Amadori, A., A. De Rossi, G. P. Faulkner-Valle, and L. Chieco-Bianchi. 1988. Spontaneous in vitro production of virus-specific antibody by lymphocytes from HIV-infected subjects. Clin. Immunol. Immunopathol. 46:342-351.

30. Amadori, A., R. Zamarchi, V. Ciminale, A. Del Mistro, S. Siervo, A. Alberti, M. Colombatti, and L. Chieco-Bianchi. 1989. HIV-1 specific B cell activation: a major constituent of spontaneous B cell activation during HIV-1 infection. J. Immunol. 143:2146-2152.

31. Spickett, G., R. Beattie, J. Farrant, A. Bryant, A. Dalgleish, and D. Webster. 1989. Assessment of responses of normal human B lymphocytes to different isotypes of human immunodeficiency virus: role of normal donor and of cell line used to prepare viral isolate. AIDS Res. Hum. Retroviruses. 5:355-366.

32. Amadori, A., and L. Chieco-Bianchi. 1990. B cell activation and HIV-1 infection: deeds and misdeeds. Immunol. Today. 11:374-379.

33. Pahwa, S., N. Chirmule, C. Leombruno, W. Lim, R. Harper, R. Bhalla, R. Pahwa, R. P. Nelson, and R. A. Good. 1989. In vitro synthesis of human immunodeficiency virus-specific antibodies in peripheral blood lymphocytes of infants. Proc. Natl. Acad. Sci. USA. 86:7532-7536.

34. Weiss, R. A., P. R. Clapham, R. Cheingsong-Popov, A. G. Dalgleish, C. A Carne, I. V. D. Weller, and R. S. Tedder. 1985. Neutralization of human T-lymphotropic virus type III by sera of AIDS and AIDS-risk patients. Nature (Lond.). 316:69-71.

35. Robert-Guroff, M., M. Brown, and R. C. Gallow. 1985. HTLV-III neutralizing antibodies in patients with AIDS and AIDS-related complex. Nature (Lond.) 316:72-75.

36. Ranki, A., S. H. Weiss, S. L. Valle, J. Antonen, and K. J. E. Krohn. 1987 Neutralizing antibodies in HIV(HTLV-III) infection with clinical outcome and antibody response against different viral protein. Clin. Exp. Immunol. 69:231239.

37. Shearer, G. M. 1983. Allogeneic leukocytes as a possible factor in induction of AIDS in homosexual men. N. Engl. J. Med. 308:223-224.

38. Shearer, G. 1983. A clinician and a scientist look at acquired immune-deficiency syndrome (AIDS): a consequence of allogeneic Ia-antigen recognition Immunol. Today. 4:181-185.

39. Shearer, G., and M. Moser. 1986. AIDS as a consequence of Ia-antigen recognition: a closer look. Immunol. Today. 7:34-36.

40. Ziegler, J. L., and D. P. Stites. 1986. Hypothesis: AIDS is an autoimmune disease directed at the immune system and triggered by a lymphotropic retrovirus. Clin. Immunol. Immunopathol. 41:305-313.

41. Via, C. S., H. C. Morse III, and G. M. Shearer. 1990. Altered immunoregulation and autoimmune aspects of HIV infection: relevant murine models. Immunol. Today. 11:250-255.

42. Rosen, A., M. Gergely, M. Jondal, G. Klein, and S. Britton. 1977. Polyclonal Ig production after Epstein-Barr virus infection of human lymphocytes in vitro. Nature (Lond.). 267:52-54

43. Hutt-Fletcher, L. M., N. Balachandron, and M. H. Elkins. 1983. B cell activation by cytomegalovirus. J. Exp. Med. 158:2171-2176.

44. Greenwood, B. M. 1974. Possible role of B cell mitogen in hypergammaglobulinemia in malaria and trypanosomiasis. Lancet. 1:435-436.

45. Kobayakawa, T., J. Louis, S. Izui, and P. H. Lambert. 1979. Autoimmune response to DNA, red blood cells and thymocyte antigens in association with polyclonal antibody synthesis during experimental African trypanosomiasis. $J$. Immunol. 122:296-301.

46. Yarchoan, R., R. R. Redfield, and S. Broder. 1986. Mechanisms of B cell activation in patients with acquired immunodeficiency syndrome and related disorders. J. Clin. Invest. 78:439-447. 
47. Amadori, A., A. De Rossi, C. Giaquinto, G. Faulkner-Valle, F. Zacchello, and L. Chieco-Bianchi. 1988. In-vitro production of HIV-specific antibody in children at risk of AIDS. Lancet. i:852-854.

48. Sedgwick, J. D., and P. G. Holt. 1983. A solid phase immunoenzymatic technique for the enumeration of specific antibody secreting cells. J. Immunol. Methods. 57:301-309.

49. Ando, D. G., F. M. Ebling, and B. H. Hahn. 1986. Detection of native and denatured DNA antibody forming cells by the enzyme-linked immunospot assay: a clinical study of (NZB $\times$ NZW) F1 mice. Arthritis Rheum. 29:1139-1146.

50. Klinman, D. M., and A. D. Steinberg. 1987. Systemic autoimmune disease arises from polyclonal B cell activation. J. Exp. Med. 165:1755-1760.

51. Ishigatsubo, Y., H. Sakamoto, E. Hagiwara, A. Aoki, A. Shirai, K. Tani, T. Okubo, and D. M. Klinman. 1990. Quantitation of autoantibody-secreting B cells in systemic lupus erythematosus. Autoimmunity. 5:71-80.

52. Monestier, M., A. Manheimer-Lory, B. Bellon, C. Painter, H. Dang, N. Talal, M. Zanetti, R. Schwartz, D. Pisetsky, R. Kuppers, N. Rose, J. Brochier, L. Klareskog, R. Holmdahl, B. Erlanger, F. Alt, and C. Bona. 1986. Shared idiotypes and restricted immunoglobulin variable region heavy chain genes characterize murine autoantibodies of various specificities. J. Clin. Invest. 78:753-759.

53. Klinman, D. M., and A. D. Steinberg. 1987. Novel ELISA spot assays to quantitate B cells specific for $\mathrm{T}$ cell and bromelated red blood cell autoantigens. $J$. Immunol. Methods. 102:157-164.

54. Freitas, A. A., B. Guilbert, D. Holmberg, G. Wennerstron, A. Coutinho, and S. Avrameas. 1986. Analysis of autoantibody reactivities in hybridoma collections derived from normal adult BALB/C mice. Ann. Inst. Pasteur Immunol. 137D:33-45.

55. Suzuki, N., T. Sakane, and E. G. Engleman. 1990. Anti-DNA antibody production by CD5 + and CD5- B cells of patients with systemic lupus erythematosus. J. Clin. Invest. 85:238-247.

56. Klinman, D. M., K. W. Higgins, and J. Conover. 1991. Sequential immunizations with rgp 120's from independent isolates of HIV-1 induce the preferential expansion of broadly cross-reactive B cells. J. Exp. Med. 173:881-888.

57. Laurence, J., F. Brun-Vezinet, S. E. Schutzen, C. Rouzioux, D. Klatzman, F. Barre-Sinoussi, J. C. Chermann, and L. Montagnier. 1984. Lymphoadenopathy-associated viral antibody in AIDS: Immune correlations and definitions of a carrier state. N. Engl. J. Med. 311:1269-1273.

58. Safai, B., J. E. Groopman, M. Popovic, J. Schupbach, M. G. Sarngad- haran, K. Arnett, A. Sliski, and R. C. Gallo. 1984. Seroepidemiological studies of human $\mathrm{T}$ lymphotropic retrovirus type III in acquired immunodeficiency syndrome. Lancet. i:1438-1440.

59. Schupbach, J., O. Haller, M. Vogt, R. Luthy, H. Joller, O. Oelz, M. Popovic, M. G. Sarngadharan, and R. C. Gallo. 1985. Antibodies to HTLV-III in Swiss patients with AIDS and pre-AIDS and in groups at risk for AIDS. N. Engl. J. Med. 312:265-270.

60. McDougal, J. S., M. S. Kennedy, J. K. A. Nicholson, T. J. Spira, H. W. Jaff, J. E. Kaplan, D. B. Fishbein, P. O'Malley, C. H. Aloisio, C. M. Black, M. Hubbard, and C. B. Reimer. 1987. Antibody response to human immunodeficiency virus in homosexual men. J. Clin. Invest. 80:316-324.

61. Klinman, D. M., R. A. Eisenberg, and A. D. Steinberg. 1990. Development of the autoimmune B cell repertoire in MRL-1pr/1pr mice. J. Immunol. 1440:506-512.

62. Leitman, S. F., H. G. Klein, J. J. Melpolder, J. Foy, F. Darr, and H. J. Alter. 1989. Clinical implications of positive tests for antibodies to HIV-1 in asymptomatic blood donors. N. Engl. J. Med. 321:917-924.

63. Friedman, S. M., M. A. Principato, G. S. Thompson, and F. Teichman. 1983. Antigen-specific and polyclonal immunoglobulin production induced by a cloned tetanus toxoid-specific T cell line. J. Immunol. 130:1164-1170.

64. Moser, M., T. Mizuochi, S. O. Sharrow, A. Singer, and G. M. Shearer. 1987. Graft-vs-host reaction limited to a class II MHC difference results in a selective deficiency in L3T4+ but not in Lyt-2+ T helper cell function. J. Immunol. 139:1355-1362.

65. Mosier, D. E., R. A. Yetter, and H. C. Morse III. 1985. Retroviral induction of acute lymphoproliferative disease and profound immunosuppression in adult C57B1/6 mice. J. Exp. Med. 161:766-784.

66. Via, C. S., S. O. Sharrow, and G. M. Shearer. 1987. Role of cytotoxic T lymphocytes in the prevention of lupus like disease occurring in a murine model of graft-versus-host disease. J. Immunol. 139:1840-1849.

67. Via, C. S., and G. M. Shearer. 1988. Functional heterogeneity of L3T4+ T cells in MRL-1 pr/1pr mice. J. Exp. Med. 168:2165-2181.

68. Klinman, D. M., and H. C. Morse III. 1989. Characteristics of B cell proliferation and activation in murine AIDS. J. Immunol. 142:1144-1149.

69. Dar, O., M. R. Salaman, M. H. Seifert, and D. A. Isenberg. 1990. Spontaneous antibodies-secreting cells against DNA and common environmental antigens in systemic lupus erythematosus. J. Autoimmun. 3:523-530. 